\title{
Multinational Corporations and Human Rights
}

\author{
BY \\ Dr. Ashu Pasricha \\ Department of Gandhian Studies, \\ Panjab University, Chandigarh - 14
}

Business enterprises that operate across national boundaries have an enormous impact on the modern world. Multinational Corporation (or transnational Corporation) MNC/TNC is a corporation or enterprise that manages production establishments or delivery services in at least two countries. Very large multinationals have budgets that exceed those of many countries. If we compare the revenues of the twenty-five largest multinational corporations (MNCs) with revenues of states, we see that only six states have revenues larger than the nine largest MNCs. If we were to include multinational banks in this figure, the power of private for-profit enterprises would be even more evident.

MNCs, because of their enormous economic power, which can sometimes be translated into political power, are beyond the effective control of national governments often raises questions. MNCs were not, in general, beyond the reach of the "sovereign" state. ${ }^{1}$ At the same time, however, most observers today agree that it is difficult for a given state to effectively regulate "its" corporations abroad for a variety of reasons. Business enterprises move resources, especially capital, rapidly around the globe, and it is only with some difficulty and a time lag that national governments know what MNCs are doing. Also, MNCs normally have considerable influence in national political systems, especially through pro-business political parties and personalities. This, of course, makes regulation of business difficult to achieve.

Moreover, it is difficult for one state to act alone in this regard. International law has not historically encouraged states to try to project extra-territorial jurisdiction in economic matters. ${ }^{2}$ And if the state did not do so, it might restrict "its" corporations in global competition so that the state received fewer economic benefits and competitors more. When in 1977 the USA passed anticorruption legislation (the Foreign Corrupt Practices Act) making it illegal for corporations registered in the country to pay bribes to get contracts from foreign parties, this put those firms at a competitive disadvantage in global competition. It was only in 1998 that the USA could persuade its partners in the Organization for Economic Cooperation and Development to level the playing 
field by adopting a multilateral convention, implemented through national legislation, on the subject. ${ }^{3}$ The logic of cooperation under conditions of anarchy, or in this case unregulated market competition, is an important subject.

The central question is not so much on the power of MNCs, or the difficulty of their regulation. Both points are readily agreed to. The more complex question is what, on balance, the impact of MNCs is on persons and their human rights in the modern world. On this there is considerable debate. It follows that there is also a lively exchange on whether there should be more public regulation of MNCs in the name of Human rights.

Few persons other than Social Darwinists look with favor on the early stages of the capitalist industrial revolution. There was a certain national economic advance that was achieved via basically unregulated capitalism, and certainly the property owners benefited. But now there is almost universal rejection of the human conditions (not to mention environmental damage) of that early industrial capitalism, illustrated by the novels of Charles Dickens. No western market democracy, and no capitalist state in any developed country, now endorses pure laissze-faire economics. Even modern political conservatives such as Ronald Reagan and Margaret Thatcher endorsed certain aspects of regulated or welfare state capitalism (Thatcher was a strong defender, for example, of the British National Health Service). Socially responsible pro-business persons recognize that capitalism is a harsh system, that not all persons benefit, that some persons require the protection of the state for a life with dignity under an economic system based on the right to private property. ${ }^{4}$ It has never proved persuasive to argue that both the poor and the rich have the same freedom to sleep under the bridges as they wish.

This brief reference to historical patterns is an important critique of unregulated business. If left to itself, even in western countries that manifested so much concern for the individual that they evolved into liberal and/or social democracies' unregulated business has often exploited, crushed, de-humanized, and affronted human dignity. Once the bonds of community, found in rural and agricultural settings, were replaced by the urban and more impersonal conditions of industrial capitalism, the have-nots were clearly in need of protection from the power of the haves. Whatever the difficulties of the political process, relatively humane national regulation of the for-profit system was achieved (at least relative to Dickens' England). The intervention of the state was used to offset the enormous power of the Henry Fords and Andrew Carnegies and the other "robber barons" of early industrial capitalism. ${ }^{5}$ One of the great problems immediately after the Cold War in places like Russia and Albania, inter alia, was that this regulation of the robber barons had yet to be made effective. This is why the successful financier, investor, and philanthropist George Soros has written that the greatest threat to democracy in the former communist lands of the Soviet Union and Eastern Europe is precisely capitalism. ${ }^{6}$ 
What has not been tolerated in the national political economies of the West for about a century, namely unregulated capitalism, has been allowed to proceed in international relations - at least until recently. And while one can chart growing international law in the domain of economics, most of that regulation is designed to encourage free trade and commercial activity, certainly not to restrict it in the name of human rights. The General Agreement on Tariffs and Trade (GATT) and the World Trade Organization (WTO) are primarily designed to encourage international capitalism, not regulate it according to social values. This was also the main thrust of NAFTA (North American Free Trade Agreement), with provisions on ecology and labor rights added only as afterthoughts when demanded by American unions and others. There is a disconnect between much of the normative framework for national capitalism (to prevent gross exploitation) and the main concern of regulation of international capitalism (to stabilize capitalism regardless of exploitation).

In the national political economy, at least from the view of nationality and with class considerations aside, we are all "us". In the international political economy, there is an "in group" "us" - and an "out group" - "them". Nationalism being what it is, as long as the benefits flow to "us" the moral imperative to show concern for "them" is reduced. The World Development Report, produced by the United Nations Development Program, regularly chronicles the large and growing gap between the wealthy global north and the impoverished global south. As one would expect in a situation of mostly unregulated international economics where a sense of global community is weak, the elites with property rights and capital prosper, and many of the have-nots live a life on the margins of human dignity. Dickens would not be surprised.

Against this background, one can easily find horror stories of unprincipled MNCs making handsome profits at the expense of clearly exploited employees and bystanders. Authors from Stephen Hymer to David Korten have chronicled the record. ${ }^{7}$ Various MNCs, from United Fruit to Coca-Cola, actively opposed progressive governments and law, designed to advance labor rights and other human rights. ${ }^{8}$ Debora L. Spar of the Harvard Business School believes that the social record of MNCs engaged in the extraction of natural resources in foreign countries has been especially poor.' On the one hand the MNC must have cozy relations with the (all-too-often reactionary) government that controls access to the resource. The MNC and local government share an interest in a docile and compliant labor force. On the other hand, the MNC has little interest in other aspects of the local population. The resource is mostly sold abroad, with a certain amount of the profits going to the governmental elite. If that elite does not act progressively to reinvest the profit into infrastructures that improve the lot of the local population, such as education, health care, and ecological protection, the MNC has seen little short-term economic interest in the situation. 
The most fundamental raison d'etre of the MNC is precisely economic self-interest, not to be a human rights actor. At least that has been the historical situation. "Investors and executives tended to see human rights as a matter for government officials and diplomats to implement, and resisted pressures to have their businesses used as tools for political reform... The globalization of the economy and the globalization of human rights concerns, both important phenomena in the second half of this century, developed separately from each other."10

Some extractive MNCs went beyond cooperation with, and active support for, a reactionary elite. United Fruit in Guatemala (1954) and ITT in Chile (1973) actively cooperated with the US government in helping to overthrow politicians (Arbenz in Guatemala and Allende in Chile) who were champions especially of labor rights for their nationals. ${ }^{11}$

To note one more example that has been much in the news, it is also reasonably clear that Royal Dutch Shell in Nigeria cooperated closely with military governments in suppressing local resistance to prevailing policies centering on extraction of oil in Ogoniland. Not only did Shell make it possible, at company expense, for the Abacha government to violently suppress those objecting to environmental degradation by Shell in Ogoniland. But also Shell refused to intercede with the government to object to the execution of Ken Saro-Wiwa, one of the most outspoken leaders of the Ogoni people in Nigeria. In reaction to considerable criticism, Shell took a number of steps to elevate the discourse about human rights as related to its business operations. But on balance the facts to date indicate that Shell has been less than fully socially responsible in its operations in Nigeria. ${ }^{12}$

At the same time that Professor Spar, as noted above, believes that extractive MNCs in particular have a poor social record, She observes that there are other types of MNCs: consumer products firms, manufacturing firms, service and information firms. Some of these, she argues, are engaged in business that is compatible with several human rights. She goes so far as to argue that MNCs sometimes export human rights values. ${ }^{13}$ According to her research, some MNCs are interested in not just cheap labor but a good labor force that is highly educated and exists in the context of stable democracy. Thus Intel chose Costa Rica for one of its foreign plants. Firms intending to sell in foreign markets have an interest in a well-paid labor force with disposable income to buy their products.

Above all, Spar argues, all firms have an economic interest in avoiding negative publicity that might damage their sales. Thus MNCs do not want to face consumer boycotts and negative publicity because of the harsh, exploitive conditions in their foreign plants, or cooperation with pariah regimes. She cites a number of firms that have altered their policies, especially to establish codes of conduct for business practices and to allow independent monitoring of labor conditions, in relation to widespread criticism: Starbucks Coffee, the Gap clothiers, Nike,' Reebok, Toys R Us, Avon, etc. She notes that a number of firms have pulled out of Burma, where a highly repressive 
military government has been internationally condemned: Levi Strauss, Macy's, Liz Claiborne, Eddie Bauer, Heineken, etc. She cites as especially effective the international campaign against child labor in the making of soccer ball, which led major MNC sporting firms to certify that no child or slave labor was used in the making of the balls.

Moreover, beyond reacting to negative publicity that might hurt the firms' bottom line on their economic books, some observers note that MNCs export standard operating procedures that are sometimes an improvement over those previously existing in a developing country. MNC plants in the global south may provide infirmaries for health care, or improved safety conditions. TNCs, even while paying wages below standards in the global north, may pay wages in developing countries that permit growth, savings, and investment over time.

After all, the Asian Tigers like Taiwan made remarkable economic progress from the mid-1950s to the mid-1990s on the basis of an economy open to MNCs. Countries like South Korea and Taiwan not only became more prosperous over time, with a skilled work force, but also became liberal and social democracies, at least relative to their past. Thus, it is argued, there is nothing inherent in the operations of MNCs that requires that they block beneficial change in host countries or that they oppose human rights standards. While they have certainly done so in the past on occasion, an emerging world of liberal market democracies, or even social democracies, would be perfectly compatible with a bottom line in the black for MNCs. After all, the major trading partners of the USA are other market democracies like Canada and the states of the European Union. One does not need gross exploitation to make capitalism work, Marxist analysis notwithstanding.

Like politicians, human rights philosophers also commonly argue that rights obligations fail only upon governments. Rex Martin's views are a typical example. ${ }^{14}$ Like many others, he argues that human rights constitute principally claims against governments because practices for recognizing and maintaining rights are purely within the domain of public (state) actors. ${ }^{15}$ Martin disputes Maurice Cranston's well-known position that "human rights are rights of all individuals against all individuals." ${ }^{16}$ Martin points out that the documents themselves identify governments as parties to the various human rights agreements States are responsible for establishing mechanisms to provide for the rights of due process, fair trials, nondiscrimination etc. At most, Martin argues, human rights might be "double-barreled," ${ }^{17}$ creating specific obligations for governments and more general obligations for society at large. The most significant responsibilities however, remain those required of states. ${ }^{18}$

Neither Martin nor Cranston, nor the schools of thought they represent ${ }^{19}$, consider the possibility that the human rights might create obligations for corporations as well. However, recent innovations in the philosophy of rights and in economic theory tend to stress the moral and social dimensions of $\mathrm{MNCs}^{20}$ This growing body of literature call be understood to argue that 
corporations do have specific moral obligations regarding the protection and promotion of human rights. Hence, any empirical study of MNCs and human rights must necessarily address the philosophical distinction between legal rights and moral rights.

Perhaps the best of these new treatments is that by Peter French, French believes that the changing nature of postmodern politics and the socioeconomic influence of large corporations often make them more important than states when it comes to impacting day-to-day life: corporate entities "define and maintain human existence within the industrialized world."21 He argues that moral claims and responsibilities are as legitimate with regard to corporations as they are with regard to individuals and governments. ${ }^{22}$

French bases his analysis of corporations as moral agents oil their ability to act according to corporate intentions. He posits that a "moral person" has the following characteristics: it is the Subject of a right, it has a capacity for accountability: and it possesses "intentionality."23 Taking corporate possession of rights and accountability for granted, French focuses oil "intentionality" as the crucial factor. A corporation must have intentions to be considered a "moral person" and to hold moral responsibilities. Corporate intentions are not the same thing as the, sum total of the individual intentions of its directors, executives, and managers. Assuming that they are synonymous is a common misconception which French refers to as the fallacy of "methodological individualism." ${ }^{24}$ Rather, corporate intentions are those regarding the "general policy" Or the "basic beliefs of the corporation,"25

Corporate intentions are produced by a process French terms corporate internal decision structures (CID Structures). ${ }^{26}$ Varying from firm to firm, CID Structures "subordinate[s] and synthesis[ze]... the intentions and acts of various biological persons" into distinct corporate intentions. ${ }^{27}$ When these basic beliefs (corporate intentions) are not followed, or when they are violated by agents of the corporation (for example, all executive acting as a loose cannon), then those actions are "no longer the policy of that company... Similarly when the corporate act is consistent with... established corporate policy, then it is proper to describe it as having been done for corporate reasons, as having been Caused by a corporate desire in other words, as corporate intentional." 28

Although French uses primarily examples from the airline industry in his analysis of corporate responsibility. his work can serve as a basis for examining corporate culpability in other contexts as well. For instance his theory of CID Structures provides one way to investigate corporate culpability in connection with the Union Carbide plant disaster in Bhopal, India.

The plant in Bhopal is part of Union Carbide of India (UCl), a majority-owned subsidiary of Union Carbide (UC). UC owns 151 percent of UCI... ${ }^{29}$ UC designed the plant ${ }^{30}$ including its safety and backup systems. ${ }^{31}$ This design lacked certain safety features built into a similar UC plant in Institute, West Virginia. United States. ${ }^{32}$ UC trained UCI personnel to run the plant. ${ }^{33}$ This training 
was not adequate to enable the UCI personnel to cope with a series of failures in the containment system that led to the disaster of 1984. The corporate structures of UC and UCI were integrated to the extent of sharing common members on their boards of directors. ${ }^{34}$

A CID Structures analysis of UC and UCI employing French's approach Would conclude that it was the corporate intention of UC that the plant in Bhopal be constructed without the safety features built into its similar US facility and that UC intended to train employees in Bhopal in such a way that the result was their inability to cope with the series of failures in the containment system that led to the disaster of 1984. Therefore, a CID Structures analysis would argue that Union Carbide, the parent company is responsible for the disaster at Bhopal, despite its initial claims that it had no direct control over the plant or its operations (which, it argued, negated any responsibility on its part).

Thomas Donaldson and Larry May construct moral arguments on collective and corporate responsibility that are similar in some respects to French's work. ${ }^{35}$ However, Donaldson and May base their analyses on philosophical grounds different from those of French's intentionality. ${ }^{36}$ Donaldson is primarily interested in applying social contract theory to corporate relations among workers, managers, and consumers.

Regardless of the differences among these views, all three authors conclude that corporations qua corporations are moral agents and therefore must accept obligations and responsibilities. Promotion and respect for fundamental human rights must be paramount among these obligations.

Two schools of thought are readily identifiable when it comes to theories of MNCs, development, and rights in the third world. One view is generally pro-MNC. Highlighting the advantages that multinationals provide for developing countries, it may be termed the "engines of development" school. The more critical or anti-MNC view stresses the negative impact of multinationals on developing nations. This theory may be termed the "Hymer thesis," because it was heavily influenced during its early development by the work of economist Stephen Hymer. Central elements of the Hymer thesis are congruent with, at times almost indistinguishable from, those of dependency theorists. ${ }^{37}$ While both views, pro-MNC and anti-MNC, were developed to identify the economic impact of multinationals, and while theorists on both sides rarely refer to human rights as such, their implications for human rights in the third world are easily derived. Competing policy proposals also support each view. 


\section{A. The Engines of Development Theory}

The pro-MNC view holds that multinationals operating in the third world directly promote economic and social rights, and indirectly support civil and political rights. If there is a positive linkage between economic development and human rights, ${ }^{38}$ then to the extent that multinationals promote development, they must also enhance human rights. Kathleen Pritchard singles out socioeconomic rights, such as the rights to unemployment protection and social security, as those rights most likely to be promoted by development. These rights "are expected to depend on the level of economic development. ${ }^{39}$ Under this theory, MNCs that promote development by creating jobs, by bringing in new capital and new technology, and by providing employee benefits such as health care, necessarily would be promoting economic and social rights.

The possible connection between MNCs and civil or political rights is Much less direct. Early theories of development advocated infusions of foreign investment and foreign business into developing Countries as a way to promote the expansion of a politically stable, urban middle class. The new middle class would in turn enhance stability and political tolerance in the larger society. ${ }^{40}$ Hence, civil and political freedoms (for example, democracy) would expand as third world nations modernized.

After World War II, US foreign policies on aid and investment were based in part oil the logic that MNCs are engines for third world development. The Alliance for Progress of the 1960s, the Reagan-Bush Caribbean Basin Initiative, the Baker Plan, the Brady Plan, President Reagan's bilateral investment treaties, and NAFTA all included provisions to open the third world to greater US investment and a larger MINIC presence. Washington often has proposed an open environment for direct foreign investment by MNCs as a tool to expand development, increase welfare, and promote democracy in the third world, all at the same time. ${ }^{41}$

\section{B. The Hymer Thesis}

A second view holds that MNCs directly contribute to violations of human rights in developing countries. The most carefully elaborated theoretical support for this position can be found in the work of economist Stephen Hymer. ${ }^{42}$ Although Hymer does not use the language of human rights, his work on the organizational structure of multinational corporations provides a strong theoretical grounding for this second view.

Hymer begins with two laws of economic development: the law of increasing size and the law of uneven development. In an often-quoted passage, Hymer describes the first law: 
Since the beginning of the Industrial Revolution, there has been a tendency for the representative firm to increase in size from the workshop to the factory to the national corporation to the multi-divisional corporation to the multinational corporation. ${ }^{43}$

Hymer predicted that multinationalization would increase greatly in the 1980s. He was correct. Hymer also argues that the first law leads directly to the second law, entailing "the tendency of the system to produce poverty as well as wealth, underdevelopment as well as development." ${ }^{44}$ This is due to the very structure of the MNC itself.

Hymer sees in this pattern of dual development a system of international domination by MNCs that leads to a deterioration of human rights in both the civil-political and the socioeconomic spheres. Hymer sees the masses of the third world, amounting to roughly two-thirds of the third world's population, as the group paying the greatest cost to maintain the system, while reaping the fewest benefits. In order to perpetuate their system of domination, multinationals "must keep the excluded two-thirds of the population under control," ${ }^{45}$ which it may do via "family planning or counterinsurgency." ${ }^{46}$ US foreign policy, at times, has been built around such counterinsurgency programs in the third world. The Office of Public Safety and the International Police Academy would be only two of the many relevant examples. These programs provided the means of repression used by many Latin American and Asian clients of the United States to violate the human rights of oppressed populations. ${ }^{47}$

In sum, if Hymer is correct, the internal organizational structure of MNCs creates dual development. Dual development creates the need to "control" the masses. In turn, instruments of control can entail repression and curtailment or denials of civil and political rights for the populations of developing countries.

Theorists and policymakers sympathetic to Hymer's view are also skeptical of the alleged socio-economic benefits for developing countries from MNC investment. They would contest claims from the engines of development school that MNCs promote economic and social rights by creating jobs, providing capital, and importing technology. Empirical studies of many developing countries, especially those in Latin America, have shown that attracting MNCs has, in some instances: eliminated more jobs than they create; ${ }^{48}$ absorbed local capital without bringing in external funds, thus harming local entrepreneurs ${ }^{49}$ and provided technology inappropriate to third world needs, hence once again doing more harm than good..$^{50}$ If MNCs do more harm than good, then they do not expand socioeconomic rights, instead, they diminish welfare in these areas.

William H. Meyer has found that the presence of MNCs and direct foreign investment is positively correlated with the practice of civil and political rights in developing countries. Those same civil and political rights were also positively correlated with higher GNP, US foreign assistance, and higher debt. Direct foreign investment was also positively correlated with the Physical Quality of Life Index, measuring longevity, nutrition, and education. Hence the author of 
this study concluded that in the modern world MNCs were engines of progressive development, associated with both improved civil-political and socio-economic rights. ${ }^{51}$ There are other optimistic accounts of the social and political workings of capitalism over time. ${ }^{52}$

Yet it remains reasonable to expect that if left alone, many MNCs will opt for short-term profits at the expense of human dignity for many persons affected directly and indirectly by their practices. It seems there must be countervailing power, either from the state, or from human rights organizations and movements, if MNC practices are to be made basically compatible with the International Bill of Rights. Given what we have noted before, namely that many parties are not enthusiastic about the IBR, effective human rights are usually wrestled from below in a tough struggle. ${ }^{53}$ The clear experience of the global north is that unregulated capitalism is injurious to human dignity and social justice.

Events in Indonesia during 1998 fit this pattern. The authoritarian Suharto government, with the support of many MNCs, clung to the status quo under the general banner of "Asian values" meaning for present purposes that authoritarian Asian states had found a model of successful economics that did not require broad political participation, independent labor unions, and other manifestations of internationally recognized human rights. There was a pattern of impressive economic growth, but the continuation of much poverty - exactly as predicted by Novak and Lenkowsky. ${ }^{54}$ But the "Asian flu" of economic recession caused a re-evaluation of "crony capitalism," led by students, labour groups, and others demanding more attention to human rights. Suharto stepped down, the succeeding government ceased to be champion of "Asian values," and numerous changes occurred. Parts of the elite took reform measures, under popular pressures, which was precisely the pattern that had obtained in the West during earlier periods.

Relevant also was the history of Nike and Reebok in Asia. Both companies had sub-contracted the production of athletic shoes soccer balls, inter alia, to firms that operated sweatshops, employed child labor, and otherwise violated internationally recognized labour rights. Negative publicity caused both companies to alter policies, and at one point Nike hired a prominent American public figure, Andrew Young, to examine some of its Asian operations. But a debate continued over whether the companies were engaged primarily in public relations and damage control, or in substantive change in keeping with human rights standards. The controversy was especially troubling to Reebok, which had pioneered certain policies related to human rights such as sponsoring rock concerts to benefit Amnesty International and making an annual human rights award. These two companies and others did participate in a program designed to guarantee that child labor was not used in the manufacture of soccer balls carrying their brand name (small fingers had proved useful in sewing). ${ }^{55}$ 


\section{INDIAN STORY}

Major economic reforms in India have been associated with crises. For example, after nearly two decades of industry-oriented planning, India accorded due importance to the agricultural sector in the late 1960s, in response to massive food shortages. The consequence of this policy shift was the Green Revolution in the early 1970s.

The economic reforms of the 1990s, the first sustained effort at restructuring the economy, came in response to another balance of payments crisis in 1991, when India was left with two weeks' import cover. The government reacted by ushering in sweeping macroeconomic and structural changes. Direct tax rates were reduced for both individuals and corporate entities, with the expectation that reduced tax rates would lead to greater compliance. Tariff rates too were reduced, and the peak tariff rate came down from 350 percent in 1990-91 to 10 percent. The structure of the other indirect taxes was rationalized, with introduction of value added tax and gst in future.

The government also made is easier for MNCs to invest in India. Today, India welcomes foreign investment in virtually all sectors except defence, railway transport and atomic energy.

All is not well with the business environment in India, however, the reforms process in India has three weak links.

- First, the policy of protecting small firms in some sectors has not completely been eliminated, thereby preventing entry of larger and more solvent firms, with greater economies of scale, to these sectors. This has had adverse impact on the competitiveness of firms in these sectors.

- Second, privatization in India has largely been a tame affair, despite some major privatization deals involving companies like the aluminum giant BALCO, the (former) telecom monopoly VSNL and the country's flagship (automobile) product Maruti Suzuki.

Successive governments have failed to meet privatization targets, and privatization of large and inefficient firms like Indian Airlines and Air India have repeatedly been postponed.

- Third, the labour code remains largely unchanged, and closure of bankrupt firms remains a difficult and tedious process. While a newly enacted legislation (in 2002) has given the financial institutions more power to recover bad loans.

2. Global Response to India's Reforms

How has the rest of the world reacted to the width and depth of the Indian reforms? 
As measured by the quantum of FDI inflow, global response has been by and large, positive but less than half of China's annual flow of FDI. Most of the firms investing in India are from the USA and Western Europe. Most of the MNCs investing in India do not have R\&D intensive products. This has serious implications for potential technology spillovers from MNC investment in India.

Most of the MNCs enter into India either with green field projects or with joint ventures with local firms

Interestingly, brand is viewed as the most important resource necessary for success. Not surprisingly, most of these firms belong to the primary, basic consumer goods, financial services and pharmaceutical sectors,

The eight resources deemed most important for success by the MNC affiliates are brand, business network, distribution network, equity, machinery and equipment, managerial capability, marketing capability and technological know-how.

Importantly, most of these are intangible resources. The MNCs feel that there has been a noticeable improvement in the quality of labour available locally across the board. The MNCs experienced a noticeable improvement in a variety of local resources - IT. professional services, real estate, machinery and equipment and raw materials. As with the overall economic reforms programme, India's performance with respect to FDI remains a mixed bag. A stagnation of the quantum of FDI inflow coexists with the perception that quality of labour and other inputs, as well as the legal- institutional environment relevant to the MNCs, have improved noticeably during the 1990s. The average MNC remains satisfied with growth in labour productivity, revenue and profits, and remains willing to transfer technological resources to the Indian affiliate.

At the same time, however, supply of key resources like power remain unreliable, and the extent of spillover effects in terms of both quality of technology and know-how remain uncertain. The appropriate mood, perhaps, is one of cautious optimism.

The post financial liberation era in India has experienced huge influx of 'Multinational Companies in India' and propelled India's economy to greater heights.

Although, majority of these companies are of American origin but it did not take too long for other nations to realize the huge potential that India Inc offers, 'Multinational Companies in India' represent a diversified portfolio of companies representing different nations. It is well documented that American companies accounts for around 37\% of the turnover of the top 20 firms operating in India. But, the scenario for 'MNC in India' has changed a lot in recent years, since more and more firms from European Union like Britain, Italy, France, Germany, Netherlands, Finland, Belgium etc have outsourced their work to India. Finnish mobile handset manufacturing giant Nokia has the second largest base in India. British Petroleum and Vodafone represents the British. A host of automobile companies like Fiat, Ford Motors, Piaggio etc from Italy have opened shop 
in India with R\&D wing attached. French Heavy Engineering major Alstom and Pharma major Sanofi Aventis is one of the earliest entrant in the scene and is expanding very fast. Oil companies, Infrastructure builders from Middle East are also flocking in India to catch the boom. South Korean electronics giants Samsung and LG Electronics and small and mid-segment car major Hyundai Motors are doing excellent business and using India as a hub for global delivery. Japan is also not far behind with host of electronics and automobiles shops. Companies like Singtel of Singapore and Malaysian giant Salem Group are showing huge interest for investment.

In spite of the huge growth India Inc have some bottlenecks, like -

- Irrational policies (tax structure and trade barriers).

- Low invest in infrastructure - physical and information technology.

- Slow reforms (political reforms to improve stability, privatization and deregulation, labor reforms).

Reports says, performance of 3 out of every 4 'Multinational Companies' has met or exceeded internal targets and expectations. India is perceived to be at par with China in terms of FDI attractiveness by 'Multinational Companies in India'. In view of 'Multinational Companies' community, it ranks higher than China, Malaysia, Thailand, and Philippines in terms of MNC performance. Multinational Companies Operating in India cite India's highly educated workforce, management talent, rule of law, transparency, cultural affinity, and regulatory environment as more favorable than others, Moreover, they acknowledged, India's leadership in IT, business processing, and $\mathrm{R} \& \mathrm{D}$ investments.

'Multinational Companies in India' are bullish on

- India's market potential.

- Labor competitiveness.

- Macro-economic stability.

- FDI attractiveness.

Thus we can say that whereas not so long ago MNCs were urged not to get involved in the domestic affairs of host states, now there has been a considerable shift in expectations; MNCs are frequently urged by citizens and their governments to undertake a more active commitment to international human rights." As a New York Times editorial noted, "quarter-century ago Americancompanies would say so today. A similar change may be developing in corporate attitudes about human rights. Companies are increasingly recognizing that their actions can affect human rights, and that respecting rights can be in their business interest." ${ }^{156}$ 
Despite the fact that public international law, and especially criminal law, does not apply thus far to MNCs, there are ways to reorient private corporations to public standards of human rights. Non-building codes of conduct, devoid of monitoring mechanisms, have proved uniformly weak in the 1970s and 1980s, whether originating from the International Chamber of Commerce, the OECD, the ILO, the US government, or in draft form from UNCTAD. But private codes, in the form of negotiated agreements, accompanied by independent monitoring and public reporting, hold dome promise for changing corporate behaviour. This is especially so when such agreements have the backing of governments which can be expected to assist in implementation. Recall that the AIP/FLA is underwritten by the US government, whose Department of Labour will carry out studies, inter alia, to promote compliance. Recall that the Rugmark campaign was underwritten by the German government.

It is in this legal gray area of public and private action that one is most likely to see progress in the near future in getting MNCs to pay more attention to human rights standards. The pressure will come mostly from the non-profit side in the context of media exposure, with the threat of consumer or citizen action that endangers the corporation's profit margin. But socially responsible partners will exist within some corporations and governments. The process is likely to remain quasi-legal and extra-judicial, although national court cases making MNCs liable for civil penalties for human rights violations could be a factor of great significance. 


\section{REFERENCES:}

1 Raymond Vernon, Sovereignty at Bay: The Multinational Spread of US Enterprises (New York: Basic Books, 1971).

2 Mark Gibney and David R. Ernerick, "The Extraterritorial Application if United States Law and the Protection of Human Rights: Holding Multinational Corporations to Domestic and International Standards," Temple International and Comparative Law Journal, 10, 1 (Spring 1996), 123-145.

3 AP, "Congress Passes Bill to Curb International Business Bribery," New York Times, October 22, 1998, A5.

4 Michael Novak and Leslie Lenkowsky, "Economic Growth Won't End Poverty," New York Times, July 24, 1985, A19.

5 E.E. Schattschneider, The Semi-Sovereign People: A Realist's View of Democracy in America (New York: Holt, Rinehart and Winston, 1960).

6 George Soros, "The Capitalist Threat," Atlantic Monthly, 279, 2 (February 1997), 45 and passim.

7 Stephen Hymer, "The Multinational Corporation and the Law of Uneven Development," in J.W Bhagwati, ed., Economics and World Order (New York: Macmillan, 197 1), 113-140; David Korten, When Corporations Rule the World (West Hartford: Kumarian Press, 1995). See also Richard J. Barnet and John Cavanagh, Global Dreams: Imperial Corporations and the New World Order (New York: Simon \& Schuster, 1994).

8 Stephen C. Schlesinger and Stephen Kinzer, Bitter Fruit: The Untold Story of the American Coup in Guatemala (Garden City, NY: Doubleday, 1982).

9 Debora L. Spar, "Multinationals and Human Rights: A Case of Strange Bedfellows," in Human Rights Interest Group Newsletter, American Society of International Law, 8, 1 (Winter 1998), 13-16.

10 Lance Compa and Tashia Hinchliffe-Darricarrere, "Enforcing International Rights through Corporate Codes of Conduct," Columbia Journal of Transnational Law, 33 (1995), 665. 
11 On Arbenz and Guatemala, see Piero Gleijeses, Shattered Hope: The Guatemalan Revolution and the United States 1944-1954 (Princeton: Princeton University Press, 1991). On Allende and Chile, see especially Richard Z. Israel, Politics and Ideology in Allende's Chile (Tempe: Arizona State University Press, 1989).

12 On Shell in Nigeria. See, for example, Human Rights Watch, The Price of Oil: Corporate Responsibility and Human Rights Violations in Nigeria's Oil Producing Communities (New York: Human Rights Watch, 1999).

13 Debora L. Spar, "The Spotlight and the Bottom Line: How Multinationals Export Human Rights," Foreign Affairs, 77, 2 (March- April 1998), 7-12. See further Kenneth A. Rodman, "Think Globally, Punish Locally: Non-State Actors Multinational Corporations, and Human Rights Sanctions," Ethics \& International Affairs, 12 (1998), $19-42$.

14 Mathew Lippmann, "Multinational Corporations and Human Rights", in Human rights and Third World Development (George W. Shepherd and Ved Nanda (eds.), 1985, p. 252.

15 Rex Marin, "Human Rights and Civil Rights" in The Philosophy of Human Rights (ed.) Morton E. Winston, 1989, p. 79.

16 Ibid.

17 Ibid.

18 Ibid., p. 80.

19 Ibid.

20 Jack Donelly, Human Rights and Human Dignity: An Analytic Critique of Non-Western Conceptions of Human Rights", American Political Science Review, 1978, Vol. 76, pp. 303, 306.

21 Thomas Donaldson, Corporations and Morality (Washington: Georgetown University Press), 1982; Peter French, Collective and Corporate Responsibility (Washington: Georgetown University Press), 1984; Larry My, The Morality of Groups (1987); Lester Thurov, Head to Head: The Coming Economic battle Among Japan, Europe and America (1992).

22 Peter French, Collective and Corporate Responsibility, op. cit., 1984, p. viii.

23 Carl Wellman, A Theory of Rights, 1985, p.145.

24 Peter French, Collective and Corporate Responsibility, op. cit., p.38. 
25 Ibid., p. 35

26 Ibid., p. 43.

27 Ibid., p. 41.

28 Ibid.

29 Ibid., pp. 43-44.

30 William Bogard, The Bhopal Tragedy: Language, logic and Politics in the Production of a Hazard, 1989, p. 4.

31 Ibid.

32 Ibid., pp.11, 13-15.

33 Ibid.

34 Ibid., pp. 4-5.

35 Ibid., p. 28.

36 Thomas Donaldson, Corporations and Morality, op. cit.

37 Peter French, Collective and Corporate Responsibility, op. cit., p.166.

38 Samir Amin, Toward and Alternative Strategy for Auto-centred Development, in Transnational Corporations and World Order, George Modelski (ed.), 1979, p. 404; Fernando Henrique Cardoso and Enzo Faletto, Dependency and Development in Latin America, 1971.

39 Kathleen Pritchard, Human Rights and Development: Theory and Data, in Human Rights and Development by David Forsythe (ed.), 1989, p. 329.

40 Ibid.

41 Daniel Lerner, the Passing of Traditional society: Modernizing the Middle East, 1964.

42 Office of Public Communication, United States Department of State, Caribbean Basin Initiative, Gist., April 1990.

43 Stephen Hymer, The Multinational Corporation and the law of Uneven Development, in Transnational Corporations and World Order, by George Modelski (ed.), op. cit., p. 386.

44 Ibid.

45 Ibid., p. 387. 
46 Ibid., p. 400.

47 Ibid.

48 Lars Schoultz, Human Rights and United States Policy Toward Latin America, 1981, pp. 168-210.

49 William H. Meyer, "Human Rights and Multi-National Corporations: Theory v. Quantitative Analysis," Human Rights Quarterly, 18, 2 (Spring 1996), 368-397; and his book making the same points, Human Rights and International Political Economy in Third World Nations: Multinational Corporations, Foreign Aid, and Repression (Westport, CT: Praeger, 1998). There followed a debate about his methods and conclusions.

50 Max Singer and Aaron Wildavsky, The Real World Order: Zones of Peace, Zones of Turmoil (Chatham, NJ: Chatham House Publishers, 1996).

51 Rhoda Howard, Human Rights in Commonwealth Africa (Totowa, NJ: Rowman \& Littlefield, 1986).

52 Michael Novak and Leslie Lenkowsky, "Economic Growth Won't End Poverty," New York Times, op. cit.

53 As with Shell in Nigeria, so with particularly Nike in Asia, there is a small library on the subject. See further, for example, Philip Segal, "Nike Hones Its Image on Rights in Asia," New York Times, June 26, 1998, 1.

54 The Dutch Sections of Amnesty International and Pax Christi International, Multinational Enterprises and Human Rights (no place: AI and PCI, no date), pp. 22-23, see further Thomas Donaldson, "Moral Minimums for Multinationals", in Joel H. Rosenthal, ed., Ethics and International Affairs: A Reader (Washington: Georgetown University Press, 1999), pp. 455-480.

55 Quoted in "Human Rights and Business: Profiting from Observing Human Rights", Ethics in Economics, 1998 (Nos. 1 \& 2), 2, 125 E. Board St., Columbus, Ohio, www.businessetics.org.

56 Michael Novak and Leslie Lenkowsky, "Economic Growth Won't End Poverty," New York Times, op. cit. 